\title{
EGF Gene Product
}

National Cancer Institute

\section{Source}

National Cancer Institute. EGF Gene Product. NCI Thesaurus. Code C118402.

A protein encoded by the EGF gene. 